\title{
Como ler “Introdução à Revolução Brasileira” de Nelson Werneck Sodré? Textualismo, contextualismo linguístico e contextualismo social ${ }^{1}$
}

Rosangela da Silva ${ }^{2}$

\begin{abstract}
Resumo: Nelson Werneck Sodré publicou, em 1958, a obra intitulada "Introdução a Revolução Brasileira" na qual afirmava que o Brasil vivenciava um processo revolucionário. Nesta obra, o autor apresenta os entraves que historicamente impediram o desenvolvimento da referida revolução - o imperialismo e os restos feudais ainda existentes em nossa sociedade - e também apresenta o agente visto por ele como capaz de conduzir este processo: a classe média, ou mais especificamente a burguesia nacional com o apoio de uma fração da classe militar. Indica, ainda, qual seria o rumo ou direção que a revolução deveria tomar: pautada no nacionalismo e na manutenção e consolidação da democracia. Diante do exposto, apresento uma análise desta obra entendendo-a como uma elaboração de um projeto político para a sociedade brasileira. Para tanto, a proposta é utilizar três abordagens metodológicas distintas: (1) o textualismo de Leo Strauss; (2) o contextualismo linguístico de Quentin Skinner; (3) o "contextualismo social” de Neal Wood e Ellen Meiksins Wood.
\end{abstract}

Palavras-chave: Nelson Werneck Sodré; Textualismo; Contextualismo linguístico; Contextualismo Social.

\section{How to read "Introduction to Brazilian Revolution" by Nelson Werneck Sodré? Textualism, linguistic contextualism and social contextualism}

\begin{abstract}
Nelson Werneck Sodré published, in 1958, the work entitled "Introduction to Brazilian Revolution" in which he claimed that Brazil experienced a revolutionary process. In this work the author introduces the obstacles that historically hindered the development of the referred revolution - the imperialism and the feudal remains that still exist in our society - and also represents the agent he sees as capable of leading this process: the middle class, or more specifically the national bourgeoisie with the support of a fraction of military class. He also indicates what direction the revolution should take: based on nationalism and maintenance and consolidation of democracy. In view of the above, I present an analysis of this work, understanding it as an elaboration of a political project to Brazilian society. For this, the proposal is using three distinct methodological approaches: (1) Leo Strauss's textualism; (2) Quentin Skinner's linguistic contextualism; and (3) the "social contextualism" of Neal Wood and Ellen Meiksins Wood.
\end{abstract}

Key words: Nelson Werneck Sodré; Textualism; Linguistic contextualism; Social contextualism.

\footnotetext{
${ }^{1}$ O presente trabalho foi realizado com apoio da Coordenação de Aperfeiçoamento de Pessoal de Nível Superior - Brasil (CAPES) - Código de Financiamento 001.

${ }^{2}$ Universidade Estadual Paulista (Unesp), Faculdade de Ciências e Letras, Araraquara - SP - Brasil. Bolsista Capes DS. Doutoranda no Programa de Pós-Graduação em Ciências Sociais. ro.toledo84@hotmail.com.
} 


\section{Introdução ${ }^{3}$}

Em 1958 Nelson Werneck Sodré publicou a obra Introdução à Revolução Brasileira - foi a partir desta que tive o primeiro contato com o pensamento do historiador - na qual afirmava que o Brasil vivenciava um processo revolucionário. Os elementos que Sodré debate de forma recorrente nesta obra são, por um lado, os entraves que historicamente impediram o desenvolvimento do mencionado processo, identificados como o imperialismo e os restos feudais ainda existentes em nossa sociedade; e, por outro, a identificação do agente capaz de dar cabo a este processo, a burguesia nacional com o apoio de uma fração da "classe" militar. Ele indica ainda qual seria, em sua perspectiva, o rumo ou direção que deveria ser dado a este processo, que seria pautado no nacionalismo e na manutenção e consolidação da democracia. Diante do exposto, fica claro que a análise proposta por Sodré se traduz em um projeto político para a sociedade brasileira. Quais são as bases teóricas sobre as quais se sustenta o referido projeto? E qual é a correlação que este autor estabelece entre ideias e realidade - que, em última instância, é o que está em jogo quando afirmamos que um pensamento se constitui em um projeto político?

Meu objeto de estudo é, portanto, teórico. Diante disso, a questão que se coloca é qual a metodologia mais adequada para estudar o referido tema? Esta escolha foi influenciada pelas discussões realizadas no Grupo de Pesquisa Democracia e Desenvolvimento - GPDD, vinculado à Unioeste, Campus de Toledo, que me possibilitou o contato com uma nova metodologia de estudo da teoria política, desenvolvida por Neal Wood e Ellen Meiksins Wood. No entanto, em que exatamente tal método se diferencia das demais metodologias utilizadas no estudo dos textos da teoria política?

Existem duas vertentes principais no que se refere à metodologia para os estudos dos textos da teoria política, a textualista e a contextualista. Sabe-se que a metodologia textualista já foi alvo de muitas críticas e que no campo do pensamento social e político brasileiro a grande maioria das pesquisas são realizadas a partir da metodologia contextualista, de maneira mais recorrente a partir do contextualismo linguístico. Porém, questiona-se neste trabalho porque não podemos seguir neste campo de pesquisa uma prática que é muito comum no interior das Ciências Sociais que diz respeito ao fato de que uma perspectiva teórica ou metodológica não inviabiliza a outra, podendo coexistir.

Nesse sentido, lançamos a seguinte questão: o textualismo é uma metodologia superada ou possui especificidades que garantem a sua relevância? E, para além disso, sendo o "contextualismo social" metodologia ainda pouco conhecida - uma metodologia contextualista, tal qual o contextualismo linguístico, qual seria o ganho em aplicar aquela em detrimento deste? E, por último, tais metodologias precisam ser analisadas como contraditórias ou podem ser empregadas como "momentos" distintos do processo de leitura e de análise de um texto?

$\mathrm{Na}$ tentativa de responder a essas questões, a proposta será, primeiro, realizar uma leitura textualista da obra "Introdução à Revolução Brasileira"» de Nelson Werneck Sodré, e, posteriormente, indicar como seria a leitura da mesma obra a partir da utilização das outras duas metodologias contextualistas ${ }^{5}$ citadas - o contextualismo linguístico tal como elaborado por Quentin Skinner; e o contextualismo social desenvolvido pela parceria entre Neal e Ellen Wood. O principal objetivo é analisar o alcance de cada uma, assim como em que medida tais abordagens poderiam ser complementares.

\footnotetext{
${ }^{3}$ A motivação para escrever este artigo para o Dossiê Contextualismo Social deriva da minha participação nos encontros do Grupo de Pesquisa Democracia e Desenvolvimento, da Unioeste, Campus de Toledo, que influenciou a definição do tema que gerou a pesquisa que está fundamentando meu doutorado. O tema está relacionado ao pensamento social e político brasileiro, de maneira mais específica ao estudo dos conceitos de "burguesia" e de "revolução" no pensamento do historiador Nelson Werneck Sodré (1911-1999).

${ }^{4}$ Que se constituiu no primeiro capítulo da tese (parte do texto com o qual qualifiquei em setembro de 2019).

${ }^{5}$ Neste trabalho, portanto, serão apresentadas apenas as questões centrais que precisam ser respondidas para um estudo realizado a partir das perspectivas das metodologias contextualistas - o linguístico e o social. Apenas como um exercício inicial de reflexão.
} 


\section{Uma análise textualista da obra "Introdução à Revolução Brasileira”}

A análise textualista da obra "Introdução à Revolução Brasileira" de Sodré será problematizada a partir do pensamento do filósofo político Leo Strauss. Este estudioso afirma que o ocidente e a modernidade estão vivenciando uma crise resultante do fato de que seus intelectuais e autoridades não acreditam mais em seu próprio projeto ${ }^{6}$. Ele propõe como resolução desta crise o retorno aos estudos dos textos da Filosofia Política Clássica. A partir daí ele empreende um esforço para mostrar de maneira detalhada como tais estudos deveriam ser realizados. A premissa básica é de que suas investigações filosóficas deveriam resultar no entendimento genuíno dos clássicos, preocupando-se com a questão da verdade contida nos referidos textos.

Na obra Perseguição e a arte de escrever: e outros ensaios de filosofia politica (2015), Leo Strauss descreve as etapas a serem seguidas em sua metodologia. Mas, antes de descrevê-las serão apresentadas algumas questões fundamentais postas por este autor diante de uma obra e autor: por que essa investigação que se pretende fazer é relevante? Ela ainda está viva? E o que esse autor do passado tem a nos dizer? Se aplicarmos - com base nas ideias contidas na obra em análise - ao pensamento social e político de Nelson Werneck Sodré tais questionamentos, em que medida é possível identificar a relevância e a atualidade de suas ideias?

Partimos do pressuposto de que esta obra de Sodré possui ainda relevância para a atualidade, pois as discussões que a compõem giram entorno de dois eixos: o primeiro trata dos entraves ao desenvolvimento do referido processo revolucionário, que ele nomeia como os restos feudais - pautadas na grande propriedade e no trabalho escravo - e o imperialismo. No segundo eixo, ele apresenta o momento em que se origina a classe média - de maneira mais específica a burguesia nacional apoiada por uma fração da "classe" militar - a qual é vista por ele como agente do processo revolucionário em curso. De modo geral, tais discussões seriam importantes para entender que tipo de capitalismo se desenvolveu no país, assim como nos possibilita analisar as especificidades da formação da nossa burguesia (classe dirigente). Questões estas que são recolocadas continuamente nos debates acadêmicos.

Leo Strauss segue dizendo que uma obra ou autor pode ser identificada como clássica quando as ideias contidas nela têm algo a dizer acerca da sociedade atual. Nesse sentido, caberia estudar Nelson Werneck Sodré como um autor "clássico" dentro do pensamento social e político brasileiro? Para Leo Strauss, a leitura desses intelectuais denominados clássicos torna-se essencial, pois somente os clássicos alcançaram a "verdade" porque não foram mediados por outras tradições. Neste aspecto, como dito anteriormente, a obra de Sodré foi publicada em 1958, período no qual as tradições do historicismo e do relativismo, vistas por aquele autor como elementos geradores da crise do ocidente, já existiam. Assim, será preciso, para interpretar o que o autor disse, efetuar o acerto de contas com a tradição que lhe é subjacente. Qual a tradição com a qual ele lida e o que ele traz, no seu próprio texto, dessa tradição? Essa será uma questão a qual buscaremos responder ao longo do desenvolvimento do texto, pois, após justificar a relevância do estudo, o próximo passo apontado por Strauss para entender as ideias de um autor consiste na leitura direta da obra sem a utilização de fontes externas, a não ser que estas estejam contidas no interior do próprio texto. É preciso ler atentamente a obra, e repetir a leitura quantas vezes forem necessárias para o seu entendimento.

Leo Strauss estabelece que compreender as palavras de um autor pode significar duas coisas diferentes: interpretação e explicação. Interpretação é "a tentativa de averiguar o que o falante afirmou e o modo como ele compreendia sua afirmação", explicação é "a tentativa de averiguar as consequências das afirmações do falante que ele negligenciava" (STRAUSS, 2015, p.150). A interpretação é, portanto, momento anterior à explicação, por isso deve ser cuidadosa, porque se for falha também o será o momento posterior. A distinção entre esses dois momentos é de grande relevância, pois, no momento da interpretação, é preciso buscar a interpretação exata do autor acerca da temática estudada. As questões

\footnotetext{
${ }^{6}$ Tal projeto estava relacionado a valores como "o universalismo, as conexões entre prosperidade e justiça e felicidade e o entendimento de ciência como a conquista da natureza a serviço do potencial humano” (TARCOV, PANGLE, 2013).
} 
levantadas neste momento são: “qual é seu tema [...]? Qual a intenção do autor ao lidar com ele? Que questões o autor levanta com relação ao tema, ou a que aspecto do tema se volta o todo, ou ao menos grande parte, de seu interesse?" (STRAUSS, 2015, p. 154). Neste momento, as questões do intérprete precisam ser colocadas em suspenso, já que o que interessa é recuperar o que o autor disse, seja buscar o entendimento original dado ao texto. Só posteriormente, na fase da explicação, o intérprete poderá fazer seus próprios questionamentos, podendo elaborar juízo de valor acerca das ideias e pensamento em estudo.

A realização deste procedimento, da leitura textualista, aplicada à obra "Introdução à Revolução Brasileira" nos conduziu a uma leitura minuciosa dos cinco capítulos que a compõem. Todos eles versavam, segundo o autor, sobre temas fundamentais para pensarmos o desenvolvimento e a constituição da sociedade brasileira, são eles: as classes sociais, a economia, a cultura, a questão militar e a questão racial.

No capítulo I - intitulado Evolução da sociedade: As classes sociais no Brasil - Nelson Werneck Sodré constrói um panorama no qual apresenta os fundamentos do processo de colonização no Brasil, os quais se apoiaram historicamente na atividade agrícola baseada na grande propriedade e na utilização de mão de obra escrava associada ao imperialismo (investimento do capital externo). Estes são, portanto, os principais entraves responsáveis pelo imobilismo da sociedade brasileira. Ao mesmo tempo, ele vai pontuando como deste terreno inóspito, no qual a terra tinha primazia e que predominavam as relações servis, surgiram os primeiros indícios da formação da classe média com base no trabalho livre. Neste sentido, o referido capítulo, que trata da Evolução da sociedade, servirá de ossatura central a partir da qual as questões serão problematizadas. Os demais capítulos - que abordam respectivamente: a Evolução da Economia; a Evolução da cultura a Evolução Militar e a Evolução racial - serão introduzidos nesta discussão a partir de interfaces que irão nos ajudar a esclarecer a noção de revolução assim como também de agente social propulsor de tais transformações, segundo Sodré. Do mesmo modo, na parte final, será analisada a importância dada por este autor para a questão do nacionalismo e do processo democrático. Entre as primeiras palavras de Nelson Werneck Sodré no primeiro capítulo está a seguinte afirmação:

Se nos fixarmos no conceito fundamental de que a sociedade se divide em classes, de acordo com a forma por que entre essas classes se reparte a posse ou o direito à posse dos bens econômicos, não poderemos deixar de sentir a evidência de que o fato característico do alvorecer da Idade Moderna foi o desenvolvimento mercantil (SODRE, 1958, p. 5).

Esta citação nos permite pontuar dois elementos importantes, o primeiro, mais evidente, referese ao fato de que o contexto mundial no século XVI, período em que ocorre o "descobrimento do Brasil", foi marcado pelo alvorecer da Revolução Comercial e das grandes navegações que marcam, ao mesmo tempo, a ascensão da burguesia e promove a liquidação da sociedade feudal. E o segundo refere-se ao fato de que este autor deixa claro qual o sentido atribuído por ele a categoria classe social.

Posto isso, ele segue suas análises afirmando que Portugal assume neste processo uma posição de destaque tanto nas navegações quanto no que se refere à sua precoce formação nacional e repartição de classes. No entanto, ironicamente, após a fase da feitoria que se resumia na comercialização do paubrasil, a atividade principal que nossos colonizadores passaram a desenvolver em sua colônia foi a atividade agrícola na qual eles não tinham tradição no seu país de origem. Portanto, a primazia que a terra adquire em nosso território é algo novo para os nossos agentes colonizadores, o que resulta em grandes mudanças nas relações de classe e na constituição de uma forma distinta de capitalismo, o capitalismo colonial. Esta forma de colonização das terras brasileiras levantou grande controvérsia a respeito da existência ou não de relações feudais na colônia. Mas, afirma o autor que:

Se nos lembrarmos que as relações feudais estavam já praticamente liquidadas com o início da Idade Moderna e de que elas jamais se revestiriam, em Portugal, de estabilidade e continuidade, e ainda de que a empresa das grandes navegações, as descobertas consequentes e o desenvolvimento mercantil pertenceram, pelas suas próprias características, a uma etapa nitidamente capitalista, verificaremos a 
inconsistência de qualquer argumento que leve à constatação da vigência de relações feudais na estrutura econômica e social da colônia (SODRÉ, 1958, p. 12).

Associado ao latifúndio foi implantado na colônia o trabalho escravo, e foi esta a equação que representou os fundamentos econômicos do Brasil por quase quatro séculos ${ }^{7}$. Neste período, "praticamente nada existe - não existe espaço para o trabalho livre, não existe coisa pública, não existe povo, e não pode existir, pois, classe média. E nem existe, de outra parte, qualquer elemento caracterizadamente pertencente à burguesia" (SODRÉ, 1958, p. 22).

Foi somente no século XVIII, com a atividade mineradora, que foi possível vislumbrar algumas alterações. Uma delas refere-se ao fato de que pela primeira vez surgia um antagonismo entre a classe dominante da colônia e da metrópole, devido à insatisfação da classe dominante colonial nos ganhos da atividade mineradora, o que estimulou movimentos em prol da autonomia. A outra grande alteração refere-se à influência das atividades mineradoras na elaboração de um esboço de mercado interno devido à necessidade de abastecimento de alimentos e utensílios de necessidades básicas dos trabalhadores. Neste contexto, a referida atividade acaba possibilitando, embora de maneira muito residual, a participação dos elementos locais na incipiente atividade comercial que sinaliza para o surgimento da classe média.

Já no século XIX, em decorrência das novas necessidades advindas com a fase do capitalismo industrial, um dos entraves ao desenvolvimento da sociedade brasileira - o trabalho servil - sofreu duros golpes que resultaram primeiramente no seu declínio culminando na sua extinção em 1888. A partir deste momento, o capital que era investido no tráfico negreiro ficou disponível para novos investimentos nas atividades urbanas, repercutindo na ampliação do mercado de trabalho, onde o trabalho livre começa a ganhar contornos mais sólidos.

Esse processo não impactou somente as áreas urbanas, pois com a mão de obra servil cada vez mais reduzida, as atividades agrícolas precisaram desenvolver novas formas de relações de trabalho, isso se verifica na cultura do café que, embora continuasse sendo desenvolvida na base do latifúndio, trouxe grandes transformações para a sociedade brasileira no que se refere às novas relações de trabalho e, também, ao financiamento de novas técnicas em diferentes setores internos, como, por exemplo, na área dos transportes, navegação, produção, comunicação e no aparelhamento bancário. Neste período podese verificar, segundo Sodré, a presença de uma burguesia no Brasil. Mas ela não chega a se definir, alinhando-se, por vezes, com a classe proprietária de latifundiários.

A análise de Nelson Werneck Sodré evidencia que grandes momentos de nossa história - como o processo de independência e da abolição da escravidão - não resultaram em grandes transformações na posição tradicional de classes. O autor completa a sua análise ao trazer para o conjunto desses grandes momentos a Proclamação da República. Nesse período se verifica a existência de grandes manifestações de inquietações de alguns grupos, sendo possível identificar maior flexibilidade na representação política das classes, mas que não foram suficientes para realizar mudanças estruturais para o quadro social brasileiro. Diferentemente, no âmbito da economia, nossa sociedade vivenciava um desenvolvimento material mais intenso com a cultura cafeeira, visto que o seu grande volume de produção colocou o Brasil pela primeira vez no quadro internacional da acumulação capitalista.

Concomitante e associado aos capitais gerados por esta produção, ocorria o crescimento demográfico vegetativo da população local e o aumento da presença de imigrantes que traziam novas necessidades que repercutiram na ampliação do mercado interno. A produção industrial alcançou pela primeira vez posição econômica relevante, embora ainda muito oscilante, pois os capitais investidos na referida produção advêm dos ganhos da produção agrícola que sofre influências do mercado externo. Outro elemento de grande importância são as sucessivas injeções de capital externo oriundo da contratação de empréstimos, em sua maior parte investidos na exploração de serviços públicos, o que

\footnotetext{
${ }^{7}$ Autores como Cardim, Gandavo, Brandônio, Gabriel Soares de Souza são citados por Sodré (1958) como intelectuais que se dedicaram aos estudos do I século do Brasil, os quais abordaram a questão da economia canavieira enquanto formadora de um quadro autárquico.
} 
gera a "impossibilidade de exploração da riqueza nacional, existente ou latente, em benefício dos próprios brasileiros" (SODRÉ, 1958, p. 45).

Fica evidente a força ainda exercida pela estrutura colonial em nossa sociedade. No entanto, Nelson Werneck Sodré chama a atenção para o espaço que a classe média passa a ocupar no quadro das atividades urbanas, desde "[...] o pequeno comércio, profissões novas, [...] o exército, o clero o funcionalismo" (SODRÉ, 1958, p. 46). Aos poucos, a classe média adquire contornos próprios. De maneira mais tímida surge a classe proletária, por ora ainda sem expressão política na vida pública nacional. A primeira metade do século XX marca o período em que a classe média e proletária - que no século passado haviam germinado - se estruturaram e marcaram posição dentro das estruturas de poder da sociedade brasileira. A classe operária passa por um rápido processo de politização devido a dois fatores: um externo, decorrente dos reflexos da Revolução Russa de 1917; e outro interno, impulsionado pelo aumento das atividades industriais. A referida politização toma como base o surgimento do Partido Comunista no Brasil (1922), que influencia as reflexões acerca das condições de vida e de trabalho do proletariado.

Em relação à classe média, o quadro lhe é favorável no sentido de que, pela primeira vez no Brasil, a produção industrial excedeu em valor a produção agrícola. Isso demonstra que o parque manufatureiro nacional se desenvolvera e alcançara certa estabilidade, formando o mercado interno e oferecendo condições para o surgimento de uma pequena burguesia. Este é um grande momento para a classe média no âmbito econômico e na vida política. Com o advento da República, Nelson Werneck Sodré afirma que a classe média chega a participar do poder por meio dos elementos militares ao citar como exemplo o governo do marechal Floriano Vieira Peixoto (1891-1894). No entanto, é frágil a presença dela nestes espaços de poder diante do grande poderio das velhas oligarquias rurais.

No âmbito econômico, as transformações advindas com o início da Segunda Guerra Mundial colocavam a necessidade de atender ao mercado interno estimulado pelo surto industrial no país, o qual favoreceu a articulação de uma burguesia nacional. Contudo, devido a nossa estrutura colonial, logo essa fração de classe passa a sofrer a influência do processo inflacionário, que, "em sua marcha inexorável, vai progressivamente corroendo a pequena burguesia, proletarizando grandes camadas da população, empobrecendo a um nível miserável grupos muito numerosos" (SODRÉ, 1958, p. 50-51). Mas, mesmo diante deste intenso processo de espoliação, os elementos da classe média e da classe proletária rural e urbana presenciaram a elaboração - ao fim do conflito mundial - de um novo cenário na sociedade brasileira, o qual dá base para "os fundamentos econômicos e uma repartição em diferentes classes suficientes para permitir aquele processo de renovação a que já se convencionou chamar Revolução Brasileira" (SODRÉ,1958, p. 51-52).

Evolução da economia: Formação da economia nacional; Evolução da cultura: Elaboração da cultura nacional; Evolução Militar: Formação do Exército Nacional e Evolução racial: A miscigenação e a sociedade são os demais capítulos que compõem a obra. Curiosamente, os títulos dos capítulos se iniciam com a palavra "evolução" e os subtítulos nos indicam que essa "evolução" nos levaria à construção ou elaboração das particularidades da nacionalidade brasileira. No segundo capítulo, intitulado Evolução da economia: Formação da economia nacional, o autor chama a atenção para a necessidade de "um profundo movimento de recuperação nacional" a partir de "um completo e objetivo conhecimento do próprio país" (SODRÉ, 1958, p.55). Nelson Werneck Sodré afirma que a história tem adquirido muita importância neste processo de autoconhecimento do que somos e quais caminhos precisamos tomar enquanto nação. Sobre esta área do conhecimento, o autor afirma:

Verificamos as transformações que sofreram as mencionadas pesquisas e estudos, ensaios e interpretações, com o passar do tempo, evoluindo de simples e quase sempre seca e cronológica exposição dos fatos [...], para as interpretações críticas em que se confere um coeficiente de importância a cada um dos fatores em jogo, ao mesmo tempo em que mostra a íntima ligação a que estão todos sujeitos (SODRÉ, 1958, p. 56). 
Para além da história da civilização que se preocupa com a dimensão política da história, Nelson Werneck Sodré defende a necessidade da constituição da história econômica com seus métodos e técnicas próprias. No que diz respeito à história econômica do Brasil, o autor propõe uma divisão em quatro fases distintas: a primeira identificada como Economia Colonial (1550-1750); a segunda Integração na Economia Mundial (1750-1850); a terceira Elaboração da Economia Nacional, e a quarta e última fase, a Estruturação da Economia Nacional iniciada em 1920 e que se constitui na fase que ainda vigorava no período em que Nelson Werneck Sodré escrevera a sua obra.

Durante todo o período que compreende as quatro fases citadas, o país vivenciou grandes mudanças em relação aos elementos que compõem a sua estrutura econômica, vislumbra-se uma luta entre a economia nacional que já está estruturada e as ingerências do poder do capitalismo imperialista. O autor compreende que a solução para este impasse é o fortalecimento dos elementos nacionais.

O terceiro capítulo, Evolução da cultura: Elaboração da cultura nacional, realiza um questionamento acerca de como elaborar o que é nacional diante de como se deu as relações entre os diferentes elementos culturais que compõem a nação. Para a análise dessa questão, estabelecemos uma interface com o quinto capítulo, Evolução racial: a miscigenação e a sociedade, no qual Sodré pensa a relação entre as diferentes "raças" em nosso país, vista pelo autor como problemática. Obviamente que este problema não é específico do Brasil, mas uma das nossas particularidades é o longo período de miscigenação entre os indígenas (nativos), os brancos (colonizadores europeus) e os negros (africanos escravizados). Para situar este problema, segundo o autor, é preciso analisar como esses elementos "se comportaram uns em relação aos outros, qual a posição que lhes foi concedida no espaço social, como foi essa posição alterada progressivamente" (SODRÉ, 1958, p. 239).

O elemento branco, representado pelo colonizador europeu, chega ao Brasil ocupando as posições de proprietário e de mando. Esse elemento exerce o poder econômico e político e atua sobre os elementos indígenas que, por sua rebeldia, foram dizimados e, posteriormente, sobre os africanos escravizados que ocupavam a posição de mão de obra para o trabalho. Neste sentido, o autor evidencia que a questão racial não pode ser isolada das relações de classe, já que o preconceito racial afirma que a inferioridade dos elementos africanos, indígenas e miscigenados é proveniente das suas ocupações históricas na estrutura de produção material.

Nelson Werneck Sodré propõe um estudo histórico-sociológico da cultura brasileira. No entanto, faz ressalvas à forma como o estudo deveria ser conduzido, pois, segundo ele, o próprio processo de constituição da sociologia no Brasil é questionável, já que, apesar de surgir tendo como objeto de estudo o social, a sua pretensão de autonomia a torna abstrata e estranha à realidade ${ }^{8}$. Em verdade, a sociologia estaria mais vinculada a questões superficiais do que aos problemas fundamentais da nação, o que acaba por elaborar também um conceito de cultura que sofre do mesmo problema. É preciso, portanto, retomar esta discussão acerca da cultura entendida enquanto desenvolvimento das ideias na sua relação com a realidade social brasileira: "[...] o estudo da sociedade constituirá o fundo em que se movimentarão conceitos, pessoas e tendências, a escala a que devemos reduzir todos os problemas e fora do qual nada de importante existe" (SODRÉ, 1958, p.115).

Os elementos elencados por Nelson Werneck Sodré como primordiais para problematizarmos a dimensão cultural da nossa sociedade são: o ensino, a religião, as artes, as ideias políticas e as letras. O ensino e a religião se constituem em duas dimensões da cultura brasileira que estão imbricadas, pois os primeiros elementos que detinham domínio da linguagem escrita no Brasil eram os missionários jesuítas responsáveis pela fundação e pelo ensino nas primeiras instituições de ensino regular. O púlpito era o espaço não só para a pregação religiosa, mas local de discussão política e outros assuntos pertinentes à sociabilidade da localidade. Porém, a erudição se fazia presente de forma reduzida ao ficar restrita apenas

\footnotetext{
${ }^{8}$ Lukács é citado nesta parte do texto para ratificar o argumento de Sodré acerca do caráter abstrato que sociologia adota, que é resultante da sua desvinculação com os problemas da sociedade (não faz referência a uma obra em específico).
} 
a esse grupo de religiosos, não se constituía em crítica concreta à organização colonial da sociedade brasileira, pois essa instrução resultava em um conhecimento abstrato e desvinculado da realidade.

Foi somente a partir do desenvolvimento da atividade mineradora que começam a aparecer elementos da intelectualidade desligados dos religiosos, sendo recrutados para desenvolver funções políticas no aparelhamento do Estado a ser organizado. Este movimento dá início à formação dos bacharéis que constituirão aos poucos a nossa classe dirigente. Porém, Sodré questiona a capacidade do elemento branco - ocupante da mais alta posição na escala social - constituído pelo colonizador português ${ }^{9}$ que compunha a classe dos proprietários em promover o desenvolvimento intelectual do país, pois eram profundamente dependentes econômica e culturalmente do exterior. Essa dependência origina o fenômeno da transplantação cultural, problema com o qual lidamos desde a independência quando nos deparamos com a necessidade de construção de uma nação independente.

No quarto capítulo, Evolução militar: formação do exército nacional, último capítulo a ser problematizado, Sodré discute o papel político e o caráter democrático que o exército teve no país. Para desenvolver tal discussão, o autor afirma ser necessário primeiramente diferenciar o papel político da força militar - que sempre esteve presente na atuação desta instituição, da vida partidária - a qual, segundo ele, a força militar não deve se envolver. Posto isso, ele passa para a análise desta instituição a partir da apresentação de suas três distintas fases: a colonial, a autônoma e a nacional.

$\mathrm{Na}$ fase colonial, as organizações de caráter militar surgem para assegurar a posse da terra. Eram em sua grande maioria organizadas no âmbito particular, o poder público pouco investia nas tropas regulares. As forças militares irregulares adquiriram muita importância, é o exemplo dos bandeirantes. Essa dimensão importante adquirida pelo privado, que resultou na criação de verdadeiras milícias em nosso território, expandiu-se também ao longo da organização política e administrativa do país. A constante situação de guerra transformou as fazendas em verdadeiros fortes, o que fez Gilberto Freyre (1933) comparar nossa zona rural com uma "sociedade semifeudal".

Foi somente após a vinda da família real para o Brasil, em 1808, que passamos a ter uma organização militar mais estável e permanente. A criação da Guarda Nacional, em 1931, que inicialmente estava subjugada ao poder metropolitano e, pós-autonomia, à classe dominante, marca o fim da fase colonial. A fase seguinte, a autônoma, foi marcada pela polarização entre a Guarda nacional e o Exército que tinha como fundamento o fato de que a primeira havia sido criada para garantir os privilégios da classe latifundiária, enquanto que o exército havia sido gestado no interior da classe média, portanto, apartado da influência da classe dominante e, justamente por isso, ocupava um papel totalmente destituído de significação.

Foi somente no episódio da Guerra do Paraguai que o exército adquire estabilidade e coesão, e que também seu elemento democrático é reafirmado ao recrutar soldados tanto entre a classe média quanto entre as classes inferiores, até mesmo escravos, o que proporcionou posteriormente que estes elementos galgassem novas patentes no oficialato, o que contribuiu para a construção de uma nova mentalidade no Exército. A partir deste momento, os chefes militares passaram a participar de maneira mais efetiva da política brasileira, o que lhes rendeu uma nova posição no quadro da vida nacional.

Terminada a guerra com o Paraguai, novas questões surgiam, como "a liberdade dos sexagenário, a reforma da lei eleitoral, a da liberdade do ventre livre", e o que era possível verificar é, como afirmou Virgínio Santa Rosa (1976), que elementos ligados ao exército nacional, que pertenciam à classe média militar, compartilhavam com a opinião dos industriais, negociantes e com a classe média civil, no que se refere à necessidade de alteração do quadro vigente, tais questões se expressam no posicionamento de alguns militares como Luís Carlos Prestes que encabeçou o movimento que ficou conhecido como "A coluna Prestes", assim como também no posicionamento de outros militares pertencentes ao movimento tenentista. Embora a classe média entre nós não tenha surgido como força econômica, ela se constituiu

\footnotetext{
${ }_{9}^{9}$ Embora alguns intelectuais, por exemplo, Francisco José de Oliveira Vianna, tenham exaltado os elementos colonizadores no que se refere ao seu alto grau de erudição, Sodré afirma que não há nada nos documentos que permita tal conclusão.
} 
como uma grande força política por meio da influência do exército, visto pelo autor com um novo poder. Como afirma San Tiago Dantas (1949), para além de recrutar seus elementos na classe média o exército possuía ainda a Escola Militar que os formavam em uma evidente contraposição das faculdades jurídicas da aristocracia rural.

Sodré afirma que no Brasil se formou uma força militar muito diversa, com características próprias. Contrariamente ao que ocorreu em muitos países, nos quais a formação do Exército Nacional se dá por influência da Revolução Burguesa, momento em que uma nova classe passa a dominar no âmbito econômico e político, no Brasil a força militar surge desvinculada das classes dominantes devido ao fato de não termos tido uma Revolução Burguesa, o que nos impediu, por consequência, a constituição do Exército Nacional. Foi somente na terceira década do século XX que a burguesia nacional passa a ter existência no Brasil. A força militar que floresce em meio a esta classe assume o papel de sua porta-voz na vida política. $\mathrm{O}$ proletariado também ganha corpo, tornando-se mais representativo e atuante. $\mathrm{O}$ surgimento e o fortalecimento de tais grupos impõem uma nova repartição de forças com os latifundiários e a alta burguesia mercantil, classes que tradicionalmente monopolizavam o poder no país.

No entanto, todas essas mudanças ocorrem em um contexto de disputas com as relações imperialistas. Esta intervenção estrangeira em nosso país, tanto por meio de empréstimos quanto de investimentos, intensificou-se a partir da segunda metade do século XIX. De maneira específica, a influência norte-americana se dá a partir da guerra com o Paraguai, e prossegue crescendo em importância em relação aos outros imperialismos na medida em que, no cenário nacional, a República vai se desenvolvendo e, no cenário externo, há o término da Primeira Guerra Mundial.

No âmbito internacional surgem importantes manifestações políticas, como o fascismo e o nazismo que influenciaram de maneira profunda o ocidente, e que, no Brasil, acabam por influenciar no estabelecimento do Estado Novo, período extremamente repressivo no país. Pela primeira vez instituiuse uma fiscalização rigorosa em relação ao recrutamento para a carreira militar. O objetivo era "vedar o ingresso naquelas escolas de elementos possivelmente refratários ao novo tratamento, especialmente os filhos de estrangeiros, os de origem judaica, os mestiços e os negros, os acatólicos, os filhos de pais divorciados ou desquitados" (SODRÉ, 1958, p. 220). Essa grande repressão que se instituía no processo de recrutamento revela que a campanha anticomunismo havia tido receptividade na classe média, e, por consequência, no exército, que representava uma de suas frações.

Nelson Werneck Sodré afirma que a ideologia deste período ditatorial do Governo Vargas foi composta pela prática policialesca, pelas tendências trabalhistas e pelas medidas nacionalistas. Isso acaba por promover transformações no âmbito econômico e político que agradarão os latifundiários, apesar de não atuar diretamente junto aos anseios de tal classe. E, ainda, promove uma aproximação desta com a classe média. O início da Segunda Guerra Mundial altera o quadro internacional das relações de poder, o que reflete também no nosso quadro interno. As forças envolvidas no conflito promovem uma repartição das nações, o Brasil, que se reaproximara dos Estados Unidos automaticamente se distancia das relações comerciais e políticas que mantinham com a Alemanha. Por consequência, promove o enfraquecimento da política instituída pelo Estado Novo, principalmente às suas ações policialescas. Embora, concomitantemente, a sua vertente trabalhista e nacionalista se fortalecia como a saída mais viável ao lado da democracia no pós-guerra.

Neste ínterim, houve o fortalecimento da produção industrial, chegando a superar os números da produção agrícola, o que evidencia uma nova sociedade na qual o poder dos grandes proprietários havia finalmente se enfraquecido, ao mesmo tempo que as novas forças sociais conseguiam representação política. Este enfraquecimento não significou a eliminação da herança colonial, esta era percebida na produção industrial que se estruturava com base em um operariado que se formara, em grande medida, a partir dos elementos vindos do campo, por meio do êxodo rural, espaço este que trazia consigo o atraso. No que se refere à retomada da perspectiva democrática, Nelson Werneck Sodré evidencia que teríamos alguns percalços. A Guerra Fria, por exemplo, iria permitir o fortalecimento das forças imperialistas com os elementos internos representados pelos latifundiários e pela burguesia mercantil, setores interessados 
na manutenção da sociedade sem alterações estruturais no campo econômico e político, portanto, que barrariam o surgimento ou restabelecimento das instituições democráticas. Neste contexto é que Sodré afirma que irá se delinear uma singular dualidade no interior do exército, que se evidencia a partir do Golpe de cúpula em 29 de outubro de 1945. A partir daí se verificará, por um lado “[...] existência de uma oficialidade de tendência democrática inequívoca, profundamente interessada na solução nacionalista dos problemas nacionais [...]” (SODRÉ, 1958, p. 223). E, por outro,

[...] a existência de um grupo de mando, rigorosamente selecionado [...] de posse das posições-chave, simulava falar em nome da instituição e, mais do que isso, agir em nome dela. A fase que medeia entre o golpe de 1945 e as eleições de 1950 assinala, desse modo, o franco predomínio, da segunda facção (SODRÉ, 1958, p. 223).

A primeira parte, de tendências democráticas, só encontra espaço para se manifestar dentro do Clube Militar. Um de seus líderes, eleito em 1950, o General Newton Estillac Leal, impulsionou de forma marcante o nacionalismo. A campanha em torno da exploração do petróleo pelos brasileiros é bem representativa deste momento. No que se refere às eleições no âmbito nacional, os grupos ligados aos interesses imperialistas tentam orquestrar novo golpe, sem alcançar êxito, Getúlio Vargas volta ao poder. No entanto, não consegue resistir às forças que lhes são contrárias. Como se expressou Sodré (1958), Vargas "deixou um testamento político cujas condenações claríssimas põem a nu a brutalidade da agressão imperialista" e que "as forças articuladas contra a democracia brasileira cuidam ter afastado o último obstáculo" (SODRÉ, 1958, p. 224). Porém, faltou ao Golpe de 1954 o apoio do exército. E, por consequência, o Movimento de 11 de novembro de 1955 demonstrou que caminhávamos para a formação do Exército Nacional.

Desta leitura atenta da obra Introdução à Revolução Brasileira de Nelson Werneck Sodré - e das referências contidas no seu interior - pudemos identificar alguns elementos centrais. Ele relata a existência, no período em que escreve - em 1958, de um processo revolucionário que está em curso, este é o tema central da obra, e de maneira específica ele busca identificar o agente propulsor deste processo, a classe média representada principalmente por uma de suas frações, os militares. No entanto, as perguntas que ele levanta acerca desta temática - que se traduzem em questionamentos acerca do porquê que tal processo não ocorreu em períodos anteriores - o direciona a um exercício de análise que retoma a história de nosso país com o intuito de identificar os "entraves" a este processo.

O latifúndio associado ao escravismo e às relações imperialistas são identificados pelo autor como tais entraves. A articulação destes elementos influenciou o desenvolvimento de um capitalismo específico em nosso país, o colonial, que, devido à natureza das relações de produção aqui desenvolvidas, foi identificado por alguns intelectuais enquanto relações semifeudais. Logo no início da obra, Sodré diz veementemente que é inconsistente afirmar a existência de relações feudais no Brasil, pois este surgiu para o mundo na Idade Moderna período em que o referido modo de produção já estava liquidado. No quarto capítulo, ele atribui a Gilberto Freyre, citando a obra Casa Grande e Senzala, a comparação de nossa zona rural com uma "sociedade semifeudal", já no fim da obra - quinto capítulo que trata da Evolução Racial - ele retoma novamente a questão, porém afirmando a existência de tais relações no país, o que fica muito confuso no sentido de saber realmente qual é o posicionamento do autor ao problematizar esta temática.

Acerca do termo classe social, o autor deixa muito claro já no início do texto qual é o seu entendimento e, por conseguinte, o tratamento que irá dar a tal categoria, pois, como exposto por ele, "a sociedade se divide em classes, de acordo com a forma por que entre essas classes se reparte a posse ou o direito à posse dos bens econômicos" (SODRÉ, 1958, p. 5). Atribui também grande importância à história nas suas análises dos processos sociais. E ainda no que se refere aos problemas raciais no país, ele afirma que tal questão não pode ser pensada dissociada da questão de como se deu a constituição das classes sociais no Brasil, seja a posição que os diferentes elementos - branco, negro e o indígena ocuparam desde o processo de colonização. Tais afirmações foram por mim elencadas no texto da qualificação como um trecho muito importante para problematizar a questão acerca da tradição com a 
qual Sodré lida, nomeei de imediato a sua vinculação com a perspectiva marxista. No entanto, no que se refere aos elementos da tradição marxista, há, no interior desta obra, apenas uma citação direta a Karl Marx $^{10}$, feita por Alcindo Sodré (1895-1952) em sua obra A gênese da desordem, utilizada por Nelson Werneck Sodré para refletir sobre o maior temor das oligarquias compostas pelos proprietários rurais que era a associação dos clubes e legiões revolucionárias, sobretudo os elementos militares, ao comunismo e ao socialismo. Sendo essa a única citação direta, em que medida a interpretação realizada não está associada ao quadro de referências do intérprete, neste caso, o meu quadro de referências? Pretende-se, com isso, frisar a dificuldade em separar as duas etapas do método textualista, a interpretação e a explicação.

Como afirma Strauss, a tentativa de compreender o que o autor disse nos levaria ao entendimento original do texto. No entanto, aí reside uma grande dificuldade, a partir da qual foram tecidas algumas das principais críticas a este método, pois, como acessar o sentido atribuído pelo autor ao texto? Evolução é outro termo que está presente nos títulos de todos os capítulos. Em todas as citações evoluir é, na sua perspectiva, a elaboração de uma cultura, de uma economia, de uma perspectiva acerca das relações étnico/raciais centradas em nossa realidade. Portanto, intimamente associada à questão da nacionalidade, visto por ele como uma das condições para a revolução. A outra condição é a manutenção e a consolidação da democracia para a qual ele aponta o Exército como uma instituição que contribui de forma efetiva para tal fim. Porém, antes de adentrar a esta discussão se faz necessário abordar a diferença entre a escrita dos capítulos que tratam da evolução da sociedade, da economia, da cultura e das relações étnico/raciais em relação ao capítulo que trata da evolução do exército.

Ao longo do texto é possível observar a existência de citações de vários autores, no entanto, nos capítulos que analisam a sociedade, a economia, a cultura e as relações raciais, as citações feitas no interior do texto não identificam o autor, referindo-se, às vezes, a "um grande estudioso", a "um grande mestre" sem nomear. Outras vezes aparece apenas trechos das obras, mas não identifica o autor nem o título, dificultando ainda mais a interpretação da obra em si mesma. Já o quarto capítulo, que trata do Exército, é visível a grande diferença na forma da escrita em relação aos demais capítulos, pois o texto obedece ao padrão da escrita científica, com citações diretas e indiretas nas quais as referências obedecem ao rigor metodológico (nome do autor, da obra e o número da página). Por que há essa diferença na escrita dos capítulos?

O gênero textual utilizado na escrita da obra Introdução à Revolução Brasileira é o ensaio, sua análise poderá nos trazer elementos para refletir acerca da forma de escrita adotada nesta obra. O ensaísmo foi dominante em nosso país até a década de 30 do século passado, este tipo de análise evidencia, como demonstra Bernardo Ricupero (2011), a possibilidade de problematizar a relação entre processos formativos distintos, assim como compreender a articulação das diferentes forças sociais existentes no interior de uma sociedade. Esta modalidade de escrita possibilita a construção de grandes narrativas, isto se aplica à obra em análise que aborda a formação da sociedade brasileira desde o Brasil Colônia até a data de sua publicação.

Como afirma o filósofo Theodor Adorno (1903-1969), "o ensaio não segue as regras do jogo da ciência e da teoria organizadas" e "não admite que seu âmbito de competência lhe seja prescrito" (ADORNO, 2003, p. 16). No entanto, "o preço de sua afinidade com a experiência intelectual mais aberta é aquela falta de segurança que a norma do pensamento estabelecido teme como a própria morte. $\mathrm{O}$ ensaio não apenas negligência a certeza indubitável, como também renuncia ao ideal dessa certeza" (ADORNO, 2003, p. 30). Na atualidade, é clara a relação de tensão entre Pensamento Social e a Ciência Política, o que traz um questionamento acerca da importância dos estudos sobre Pensamento Social visto por alguns intelectuais como produções pré-científicas e de certa maneira associada a uma espécie de filosofia política que se pergunta acerca do "dever ser", em um momento em que a Ciência Política está

${ }^{10}$ Nesta citação de Alcindo Sodré a citação se refere a Carlos Marx. 
consolidada em nosso país, o que impõe um novo padrão intelectual baseado na ciência, que supostamente busca responder o que as coisas ou fatos "são".

O método de análise textualista, que é um método fundamentalmente filosófico, pertence à área do conhecimento que busca se atentar para a totalidade. Como nos diz Léo Strauss, tais estudos se ocupam de textos clássicos que tinham como objetivo a busca pela verdade, pelas ideias atemporais. Embora Nelson Werneck Sodré afirme, na sua crítica acerca do processo de transplantação, que nem tudo que vem de fora é ruim pelo simples fato de ser externo, já que "as criações verdadeiramente grandes, aquelas tocadas pelo signo da eternidade, são universais" (SODRÉ, 1958, p.134), sua obra se distancia em alguma medida das proposições metodológicas de Leo Strauss na medida em que as obras de Nelson Werneck pertencem à tradição ensaística, um texto diferente dos textos analisados por Leo Strauss que, segundo este, são obras que foram elaboradas para especialistas - que somente o leitor atento, o verdadeiro filósofo entenderia. A obra de Nelson Werneck Sodré parece não ter essas pretensões, a própria palavra "introdução" contida no título nos remete a essa interpretação, indicando que o autor buscava iniciar uma discussão - historicamente situada - e não dar conta de sua totalidade.

Para além das diferenças acima nomeadas, é importante frisar também que o capítulo quarto narra o surgimento do exército no Brasil e a sua constituição enquanto uma instituição democrática. A base para essa discussão foi posta por Sodré no primeiro capítulo de sua obra, no qual ele discute a evolução da sociedade entendido por ele como a constituição das classes sociais no país. Este processo só começa a se configurar, na perspectiva deste autor, com a atividade mineradora no século XVIII, pois, como exposto anteriormente, antes deste período "praticamente nada existe - não existe espaço para o trabalho livre, não existe coisa pública, não existe povo [...]” (SODRÉ, 1958, p. 22).

Algumas das grandes transformações ocorridas neste período e que impactam diretamente na formação das classes sociais são: surgimento de um antagonismo entre a classe dominante da metrópole e da colônia que resultaram nos movimentos em prol da autonomia; a necessidade de abastecimento de produtos alimentícios e de primeira necessidade para os envolvidos na atividade mineradora resultou no desenvolvimento dos núcleos urbanos e um esboço de mercado interno que, por consequência, resultou no surgimento de novas profissões ligadas às atividades urbanas, o que deu condições para o estabelecimento e expansão da classe média. E, ainda, posteriormente, quando a produção industrial excedeu em valor a produção agrícola estávamos diante de um quadro favorável para o surgimento de uma pequena burguesia e expansão do proletariado. No entanto, para além da sua constituição, Sodré se pergunta acerca de como se dá a atuação dessas diferentes classes no âmbito político.

A resposta elaborada por Sodré para essa questão passa pela íntima relação existente entre a classe média e a formação do exército, pois este foi gestado no seu interior. Diferentemente da Guarda Nacional (1931) que foi criada para atender aos privilégios da classe dirigente - formada pela oligarquia rural, o exército reafirma seu elemento democrático no episódio com a guerra do Paraguai ao recrutar soldados de todas as classes sociais, inclusive escravos. A partir daí essa instituição, imbuídos desta nova mentalidade, passou a ter mais coesão, estabilidade e representatividade política. Muitos de seus elementos representaram - em alguns momentos políticos - os interesses de toda a sua classe, a classe média, como também de outros segmentos, como da pequena burguesia e o proletariado. Porém, Sodré deixa claro que esse importante papel político do exército não deve ser confundido com atuação partidária. 


\section{Uma análise contextualista da obra "Introdução à Revolução Brasileira" - procedimentos via contextualismo linguístico (elementos introdutórios)}

Quentin Skinner afirma que o textualismo é um método que possui algumas limitações. De início, ele questiona duas premissas básicas dessa metodologia: a crença de que as reflexões elaboradas pelos clássicos tratavam de um conjunto de "problemas fundamentais", o que garantia sua "relevância perene", e a afirmação de que, para acessar o sentido de um texto, é preciso entender o que o autor disse (SKINNER, 2005, p.82). Antes de apresentar seus argumentos é importante ressaltar que suas reflexões foram para além da mera crítica, pois ele contribuiu para a elaboração de uma nova metodologia para o estudo das ideias políticas, o contextualismo linguístico.

No que tange à primeira questão, o entendimento de Quentin Skinner é de que não basta compreender nos textos clássicos aquilo que eles têm a nos dizer sobre os temas eternos, os clássicos responderam questões de um momento específico, para um público específico:

Pois entendo que a própria vida política coloca os principais problemas para o teórico da política, fazendo que um certo elenco de pontos pareça problemático, e um rol correspondente de questões se converta nos principais tópicos em discussão". Nesse sentido, é preciso conhecer "as características mais relevantes das sociedades nas quais e para as quais eles originalmente escreveram (SKINNER, 1996, p. 10).

Segundo essa afirmação de Skinner, é necessário, portanto, situar a obra em seu tempo. No caso da Introdução à Revolução Brasileira quais eram as principais questões que Sodré se deparava no período em que a escreve? Para fazer tal análise é preciso ir além desta obra, Skinner acredita que, para compor o quadro das ideias políticas da época, é também de fundamental importância, para além da leitura dos textos dos clássicos, ler os escritos de autores "menores", ou efêmeros, que escreveram no mesmo período. Tais assertivas evidenciam que esse autor inclui em sua metodologia a análise do contexto em que o texto foi produzido. O contexto do qual fala é o linguístico, para entender o sentido de uma obra é preciso identificar "as convenções linguísticas reconhecíveis da época" em que o texto foi escrito. "Pois é evidente que a natureza e os limites do vocabulário normativo disponível em qualquer época dada também contribuirão para determinar as vias pelas quais certas questões em particular virão a ser identificadas e discutidas" (SKINNER, 1996, p. 11).

Seguindo esta orientação do contextualismo linguístico, iremos problematizar outras obras que foram produzidas no mesmo período da obra em estudo, são elas: A Revolução Brasileira (1966) de Caio Prado Júnior (1907-1990); e A Revolução Burguesa no Brasil (1975) ${ }^{11}$ do cientista social Florestan Fernandes (1920-1995). Ambas tratam de um processo revolucionário que estava em curso no país e, por isso, serão abordadas aqui como produções que compartilham o mesmo contexto intelectual da referida obra de Nelson Werneck Sodré. É importante frisar que Caio Prado Jr. e Florestan Fernandes não podem ser enquadrados como autores "menores" ou secundários do período, muito pelo contrário, são vistos, cada um em sua respectiva área, como autores clássicos. Portanto, nosso recorte vai ao encontro das afirmações de Gildo Brandão (2010) da grande importância de estudarmos também os teóricos que produziram pensamentos que são muito representativas para a época.

Os títulos das três obras têm em comum a palavra "revolução", de modo que poderíamos afirmar que os três autores convergem na análise de um suposto processo "revolucionário" em curso no Brasil. Porém, a despeito da proximidade histórica no que se refere ao ano das publicações - entre o final da década de 50 e metade da década de 70 do último século; da adoção do estilo ensaístico; e do fato de que compartilham uma perspectiva teórica semelhante, de orientação marxista; uma análise das três obras revela muito mais divergências do que se poderia supor, como, por exemplo, os diferentes agentes apontados por cada autor - Sodré: a Burguesia Nacional; Prado Jr.: os trabalhadores rurais e urbanos;

\footnotetext{
${ }^{11}$ É importante ressaltar que Florestan Fernandes publica a obra Revolução Burguesa no Brasil em 1975, no entanto, ele inicia os
} escritos que irão compor a referida obra na década de 60. 
Fernandes: os imigrantes e os produtores de café - como responsáveis pelo processo revolucionário. Como explicar que três intelectuais "marxistas", ao analisarem o que consideravam um "processo revolucionário" no Brasil, tenham produzido obras que possuem diferenças significativas?

A abordagem contextualista de Skinner, a qual revitaliza a importância do estudo das ideologias, possibilita que a pergunta que faziam os textualistas, o que o autor disse, seja reelaborada no contextualismo linguístico, concentrando-se na busca do entendimento do que o autor quis dizer, ou seja, passa a se perguntar acerca da intenção do autor. Esse deslocamento se dá por que, para Quentin Skinner, não é possível acessar o que o autor disse, pois o quadro de referências (expectativas e preconceitos) de quem está empreendendo o estudo da obra é diferente do quadro de referências do autor do texto (SKINNER, 2005, p. 82).

A tentativa de elaborar estudos a partir dessa premissa, a busca pelo o que o autor disse, pode resultar em absurdos históricos, os quais ele denominou de mitologias: são elas a mitologia das doutrinas, da coerência e da prolepse. A "expectativa de que cada autor clássico teria enunciado uma doutrina acerca dos temas considerados constitutivos da disciplina" foi nomeado por ele de mitologia das doutrinas.

Essa mitologia das doutrinas resulta em dois absurdos históricos: um deles é a construção de uma percepção unitária acerca do pensamento do autor, e outro resultaria no anacronismo que "consiste em supor que ele \{o autor\} poderia ter tido a intenção de contribuir para um debate cujos termos não estavam ao seu alcance" (SKINNER, 2005, p. 85-86); a mitologia da coerência, traduz-se na ambição de analisar os textos buscando encontrar uma coerência interna neles, mesmo que não os tenha; por fim, $a$ mitologia da prolepse, "quando pensamos no significado que um dado texto pode ter para nós, torna-se mais fácil, em primeiro lugar, descrever essa obra e a sua alegada relevância de forma a não permitir análises acerca do que o seu autor pode ter pretendido dizer" (SKINNER, 2005, p.104).

Quentin Skinner reitera que os "significados dos termos que utilizamos para expressar os nossos conceitos mudam com o tempo" (SKINNER, 2005, p. 113), nesse sentido é importante atentar para os "usos" que se faz de tais conceitos. Precisamente, trata-se de saber "o que o autor estava fazendo quando escreveu a obra":

Disso resulta que a correta compreensão de uma ideia ou teoria só poderia se dar pela sua apreensão no interior do contexto em que foram produzidas. Resulta também que o objeto de análise historiográfica é deslocado da ideia para o autor, do conteúdo abstrato da doutrina para a ação ou performance concreta do ator num jogo de linguagens historicamente dado (JASMIN, 2005, p. 28).

Tal análise permite pensar uma articulação entre as dimensões teóricas e práticas, pois “a fim de explicarmos por que tal agente faz o que faz, será preciso referirmo-nos a seu vocabulário, já que este com toda a evidência se delineia como um dos fatores a determinar sua ação" (SKINNER, 1996, p.12). Neste sentido, perguntamo-nos aceca do que Sodré estava fazendo quando escreveu a obra Introdução à Revolução Brasileira?

Essas afirmações de Skinner traz luz para algumas das questões que não foram possíveis responder a partir do textualismo - interpretação a qual está circunscrita apenas ao texto e às referências internas a ele. Uma das questões que mais causou estranhamento - quando fiz a leitura da primeira edição - refere-se à forma da escrita da obra, pois o quarto capítulo, que trata da Evolução Militar, possui grande diferença em relação aos demais capítulos. Com a permissão do contextualismo linguístico no que se refere à busca pelo contexto, acabei tendo contato com diferentes edições da obra, de maneira específica a quarta edição, publicada em 1978, traz um prefácio esclarecedor. A suposta incoerência entre os capítulos deve-se ao fato de que esta obra é uma compilação de conferências pronunciadas por Sodré entre os anos de 1954 e 1956.

Já na segunda edição, publicada em 1963, esta obra foi reorganizada. O capítulo sobre o Exército foi suprimido - o qual foi ampliado e publicado em 1965 como livro à parte, intitulado a História Militar do Brasil - e acrescentou-se um capítulo que trata da Evolução Política, como resultado de uma conferência 
apresentada como aula inaugural no Instituto Superior de Estudos Brasileiros -ISEB, em 1959. E, ainda, o capítulo sobre a Evolução Popular, publicado na coleção Cadernos do Povo Brasileiro de 1962. A terceira edição, datada de 1967, passa a incluir um outro capítulo intitulado Perspectivas, que já traz uma análise dos acontecimentos ocorridos com o Golpe de 1964.

O autor faz questão de frisar que esses diferentes textos que compõem a obra Introdução à Revolução Brasileira nas suas diferentes edições foram escritos em datas e conjunturas diferentes e que, portanto, refletem de maneira diferente na construção do seu pensamento. Porém, de qualquer maneira, todos os textos que se tornaram capítulos desta obra foram redigidos após 1950, período de sua maturidade intelectual. Portanto, seus escritos já possuíam as marcas de suas principais influências teóricas. Como nos diz José Paulo Netto (2011), Sodré viveu entre duas vocações, a das armas, pois era militar, e a das letras, deixou-nos uma vasta obra que aborda diversas temáticas como: a literatura, a sociedade, a cultura, a política e o exército brasileiro. Era também membro do Instituto Superior de Estudos Brasileiros ISEB e possuía vinculação com o Partido Comunista - PC.

No que se refere à sua perspectiva acerca dos elementos definidores das classes sociais, a importância atribuída por ele ao processo histórico, assim como também sua afirmação de que a questão racial/étnica precisa ser analisada associada à questão social é facilmente localizada no âmbito da perspectiva marxista por seus intérpretes Netto (2011), Silva (2001) e Cunha (2011), alguns desses o apontam até mesmo como ideólogo do Partido Comunista. No entanto, diante disso, fica ainda obscuro quando afirma o papel democrático do exército, no sentido de que seus oficiais possuíam importante papel político, porém, nega a atuação partidária.

\section{Uma análise contextualista da obra "Introdução à Revolução Brasileira" - procedimentos via contextualismo social (elementos introdutórios)}

O método de estudos dos clássicos da política chamado aqui de "contextualismo social"12 foi elaborado por Neal Wood (1922-2003) no artigo The social history of political theory e aplicado por ele e por Ellen Meiksins Wood em diversas obras. Farei uso do texto O contextualismo social de Neal Wood e Ellen Meiksins Wood: uma introdução, elaborado por Vania Sandeleia Vaz da Silva (2016), que se traduz em um esforço de apresentar, de maneira concisa, uma sistematização do referido método. Neal Wood (1978) afirma que sua proposta para o estudo dos textos dos clássicos da teoria política traz uma inovação no que se refere à compreensão dada ao contexto se comparada a outras metodologias contextualistas, como o contextualismo linguístico e o contextualismo sociológico. Tais diferenças serão pontuadas abaixo, ao longo da apresentação dos procedimentos de como realizar a essa contextualização. O conjunto de assertivas das quais partiu Neal Wood são, como exposto por Silva (2016):

(1) a política é um empreendimento eminentemente prático; (2) a teoria política clássica está intimamente relacionada com o contexto social e histórico prático no qual foi concebida; (3) cada texto clássico de teoria política, entre outras coisas, é uma importante reflexão sobre seu tempo; (4) a gênese de uma obra clássica de teoria política pode ser explicada em termos sociais, representando fundamentalmente uma posição partidária no conflito do período; (5) consequentemente, toda obra clássica de teoria política é ideológica, embora não exclusivamente (SILVA, 2016, p. 89).

De posse do conhecimento dessas assertivas, que nos indica a forma como esse autor interpreta a política e os textos acerca da teoria política elaborados pelos clássicos, passamos para as diferentes etapas que irão nos dizer como realizar a contextualização. A primeira delas é delinear o contexto social em que a obra foi escrita, a partir da leitura de obras históricas, sociológicas, econômicas, políticas, entre outras, o

\footnotetext{
12 Essa metodologia vem sendo estudada pelo Grupo de Pesquisa Democracia e Desenvolvimento do qual faço parte. A terminologia foi cunhada pelo referido grupo. Ver: (O artigo do Projeto elaborado por Neres, Dombrowski E Silva, publicado na Revista Tempo da Ciência, v.23, n.45, 2016), os primeiros resultados foram apresentados por Helanski, Silva e Neres (2016).
} 
objetivo é compreender a sociedade em que o autor viveu, buscando identificar qual era o conflito da sua época, nesse momento é importante tentar identificar aspectos como "a natureza da estrutura social real, da divisão de classes, do sistema prevalecente de status, das conexões entre classes e status e suas relações com o Estado" (SILVA, 2016, p. 90).

Tabela 1. Aspectos relacionados ao contexto social em que o autor escreveu a obra em análise, que permitem compreender como suas ideias se relacionam com a estrutura de classes e o conflito social

\begin{tabular}{|l|l|}
\hline 1 & Quais classes estão ascendendo e quais estão declinando? \\
\hline 2 & Qual o grau de consciência de classe [class consciousness]? \\
\hline 3 & A estrutura de classes está refletida nos arranjos governamentais? \\
\hline 4 & A estrutura de classes está refletida no sistema de dominação e subordinação? \\
\hline 5 & Como as divisões religiosas na sociedade estão relacionadas com a vida econômica e política? \\
\hline 6 & Como as divisões étnicas na sociedade e como estão relacionadas com a vida econômica e política? \\
\hline 7 & Quais os modelos aceitáveis de conduta social? \\
\hline 8 & Quais as várias tendências intelectuais ou escolas de pensamento? \\
\hline 9 & Quais são seus temas centrais? \\
\hline 10 & De que modo estes temas estão relacionados com as lutas sociopolíticas do período? \\
\hline 11 & Podemos nos referir às raízes sociais do conflito intelectual? \\
\hline 12 & As linhagens intelectuais refletem as divisões de classe ou outras clivagens sociais? \\
\hline
\end{tabular}

Fonte: Silva (2016, p. 99).

O trabalho de contextualização de Nelson Werneck Sodré consistiria, portanto, em responder as questões acima a partir dos livros, teses e dissertações que tratam do período em que ele viveu. Após situar a obra em seu contexto, é preciso situar o próprio autor a partir de sua biografia - leituras de obras já existentes - procurando entender como ele se posicionou diante desse conflito. No caso específico do autor em estudo, para além das biografias elaboradas por seus intérpretes, ele próprio escreveu duas obras autobiográficas Memórias de um soldado (1967) e Memórias de um escritor (1970) as quais retratam muito bem a sua vida no exército e enquanto intelectual.

Tabela 2. Aspectos relacionados à biografia que permitem situar o autor na sociedade

\begin{tabular}{|l|l|}
\hline 1 & Quem era a família do teórico e quais suas conexões familiares? \\
\hline 2 & Como foi sua educação e também sua formação intelectual? \\
\hline 3 & Quem eram seus amigos e associados? Sua educação? Sua religião? Sua situação econômica? \\
\hline 4 & Qual a sua profissão, ofício ou ocupação? \\
\hline 5 & Quem era seu empregador ou patrão? \\
\hline 6 & Qual era seu estatuto legal? \\
\hline 7 & Quais suas funções econômicas reais? \\
\hline 8 & Quais as fontes e a extensão de sua renda? \\
\hline 9 & Como era seu modo de vida? \\
\hline 10 & Quais suas atividades políticas? \\
\hline 11 & Quais suas afiliações políticas? \\
\hline 12 & Quais seus laços religiosos? \\
\hline 13 & Qual o gênero/identidade/orientação sexual (heteronormatividade)? \\
\hline 14 & Qual sua “etnia" e qual a situação dessa na sociedade em questão? \\
\hline
\end{tabular}

Fonte: Silva (2016, p. 100). 
O que é central, pois, na visão de Neal Wood (1978), é que os teóricos políticos clássicos não foram expectadores neutros dos conflitos, eles se posicionavam, seus escritos eram elaborações comprometidas com a defesa de uma posição sociopolítica. Essa forma de proceder possibilita, segundo Neal Wood, uma análise contextual informada pela história social em sentido mais amplo, pois "contexto" nesse caso refere-se ao econômico, social, político e ideológico. Nesse ponto, é possível identificar importante diferença em relação ao contextualismo linguístico, pois, para essa metodologia, o contexto que importa é o intelectual, e este se constitui a partir de convenções linguísticas reconhecíveis de cada época, as quais podem "determinar" ou constranger a prática política. O contextualismo social é um método identificado por seus próprios autores, Neal e Ellen Wood, como uma vertente marxista do modo histórico de análise, no entanto, uma vertente que se distancia do contextualismo sociológico, pois não é um modo determinista de entender as ideias políticas. A relação entre base e superestrutura se dá de maneira orgânica, onde as ideias não são vistas como meros reflexos das relações materiais.

Tabela 3. Aspectos relacionados ao ideal bumano - herói e anti-herói do teórico clássico

\begin{tabular}{|l|l|}
\hline 1 & Como o teórico pensa que os seres humanos devem ser e agir? \\
\hline 2 & Que tipo de ser humano deve dominar a sociedade? \\
\hline 3 & Que tipo humano - real ou imaginado - carrega a melhor promessa para o futuro? \\
\hline 4 & Como o teórico visualiza o indivíduo que mais plenamente realiza esse potencial humano? \\
\hline 5 & Quem na sociedade como está atualmente constituída é mais capaz de atingir esse ideal? \\
\hline 6 & Esse ideal é atingível por qualquer um ou apenas por poucos? \\
\hline 7 & O abismo entre os homens que existem e o ideal humano é grande ou pequeno? \\
\hline 8 & Sob quais condições pode o ideal humano ser mais rapidamente realizado? \\
\hline
\end{tabular}

Fonte: Silva (2016, p. 101).

O próximo passo, a identificação do ideal humano, ajuda-nos a entender essa relação, uma vez que o ideal humano de um dado autor foi construído a partir de um homem concreto, recortado do contexto em que o autor estava vivendo, relacionando, portanto, a teoria com o contexto social. Identificar o "ideal humano" de cada teórico, quer dizer, o tipo humano que seria seu herói ou anti-herói, os elementos que cristalizam sua adesão a determinados objetivos sociais e políticos e sua rejeição a outros, permitem-nos compreender suas prescrições sociais e políticas. No caso de Sodré, que era adepto do nacionalismo, acreditamos, a princípio, que o seu anti-herói pode ser identificado como os líderes políticos ou agentes econômicos adeptos ao imperialismo econômico e encorajadores da transplantação cultural, enquanto que seu herói é construído a partir de uma fração da classe militar - da qual ele fazia parte - alinhados com os interesses democráticos.

Tabela 4. Prescrições para realização do ideal bumano

\begin{tabular}{|l|l|}
\hline 1 & Quem deve governar? \\
\hline 2 & Quem deve ser governado? \\
\hline 3 & Como os governantes devem governar? \\
\hline 4 & Como os governados devem obedecer? \\
\hline 5 & $\begin{array}{l}\text { Quão grande é a distância que existe entre a situação sociopolítica real na qual o teórico está } \\
\text { escrevendo e sua visão de uma ordem cívica reconstituída na qual seu ideal humano típico pode } \\
\text { florescer? }\end{array}$ \\
\hline 6 & Como essa lacuna pode ser preenchida? \\
\hline
\end{tabular}

Fonte: Silva (2016, p. 101). 
Por fim, só depois de todas essas etapas de análise é possível identificar o que tem de contingente, e o que pode ser visto como universal - não em um sentido absoluto, mas a respeito de um contexto mais amplo - nas ideias contidas na obra em análise. No caso da obra em análise, seria importante discutir quais elementos contidos na obra de Sodré que podem ter relação com processos que ainda teriam validade para além do seu tempo e para outros contextos.

Tabela 5. Delimitar a especificidade histórica das ideias do teórico

\begin{tabular}{|l|l|}
\hline 1 & O que eles estavam tentando dizer aos seus contemporâneos? \\
\hline 2 & Sob quais condições estavam dizendo isso? \\
\hline 3 & Por que e com quais interesses estavam dizendo isso? \\
\hline
\end{tabular}

Fonte: Silva (2016, p. 101).

No momento atual, após a qualificação, minhas investigações se direcionam no sentido de entender como posso aplicar ao meu objeto de estudos as premissas do contextualismo social. A afirmação de que a partir deste método é possível ampliar a noção de contexto para além do linguístico, abrangendo também o econômico, social, político e ideológico, possibilita trazer para o estudo novos elementos. Um deles é o pressuposto de que todo intelectual ao escrever sua obra o faz de maneira posicionada, portanto, toda obra é ideológica.

Neste sentido, cabe analisar qual era a posição de Nelson Werneck Sodré no conflito da época em que escreve a obra Introdução à Revolução Brasileira - para tanto, será analisado, para além de suas obras, um conjunto de cartas do seu acervo pessoal e também pretendemos realizar uma entrevista com sua filha Olga Sodré - o que poderia nos dar pistas de como entender a sua afirmação que, por um lado, reconhece o importante papel político desempenhado pelo exército, mas que, por outro, nega a esses elementos a posição partidária embora seja ele próprio militar e reconhecidamente comunista.

Nelson Werneck Sodré foi um intelectual longevo, morreu aos 87 anos. Vivenciou importantes momentos históricos da política brasileira, alguns deles os quais justificavam a sua crença no comprometimento do exército com a causa militar, porém, vivenciou também o período do Golpe Militar de 64, no qual presenciou a instituição que havia parido seu herói se alinhar a uma perspectiva autoritária, a qual causou um retrocesso no país no que se refere ao desenvolvimento democrático. Tinha como característica também a contínua revisão de suas obras, o que indica a necessidade de incluir no trabalho a leitura delas e a sua releitura após os acontecimentos mencionados acima, buscando entender como ele se posiciona nos diferentes momentos do processo histórico do país. 


\section{Considerações finais}

Deste exercício inicial de reflexão podemos esboçar algumas tentativas de respostas as questões postas na introdução. Partimos do pressuposto de que as metodologias textualista e as contextualistas aqui representadas pelo contextualismo linguístico e o contextualismo social - embora sejam diferentes, necessariamente não precisam ser percebidas enquanto contraditórias, podendo ser identificadas como etapas ou momentos distintos do processo de leitura e de análise de um texto.

A atividade de leitura de um texto, para fins de conhecimento e apreensão de seu conteúdo, como ocorre quando do estudo de um texto, realiza-se por meio de uma sequência de etapas essenciais: etapa de análise textual; etapa de análise temática; etapa de análise interpretativa; etapa de problematização; etapa de reelaboração reflexiva (SEVERINO, 2014, p. 14).

A experiência vivenciada durante a escrita do texto da qualificação, assim como também as contribuições recebidas pelos professores da banca, reafirmam esta perspectiva, no entanto, embora os resultados da análise da etapa textualista tenham grande importância, parecem contribuir muito mais para a organização interna do pensamento do intérprete do que para guiar a escrita.

Neste sentido, a amplitude dos métodos contextualistas são inquestionáveis. Uma das principais críticas ao capítulo I do meu texto de qualificação, que se constituía a partir da leitura textualista da obra Introdução à Revolução Brasileira, reside no fato de que somente na página cinquenta é possível saber quem é Nelson Werneck Sodré, ou seja, isso se deve ao fato de que temos como hábito conhecer o autor primeiramente a partir de seus intérpretes, das correntes teóricas às quais ele está filiado e só posteriormente fazer a leitura de seu próprio texto.

O contextualismo linguístico de Quentin Skinner atende a essas expectativas, pois, no lugar das reflexões acerca das verdades eternas, este autor afirma que toda obra foi escrita em um momento histórico específico e para um público específico. O resultado do seu posicionamento é a relevância dada ao contexto de produção da obra. No entanto, o referido contexto do qual trata é o linguístico o que o torna ainda limitado diante do contextualismo social que o entende como a junção dos âmbitos social, político, econômico e ideológico. 


\section{Referências}

ADORNO, Theodor. O ensaio como forma. Notas de literatura I. São Paulo: Duas cidades, 2003.

BRANDÃO, Gildo Marçal. Linhagens do pensamento político brasileiro. São Paulo: Hucitec, 2010. CUNHA, Paulo Ribeiro da. Um olhar à esquerda. A utopia tenentista na construção do pensamento marxista de Nelson Werneck Sodré. 2. ed. Rio de Janeiro: Revan, 2011.

HELANSKI, Juliane; SILVA, Vania Sandeleia Vaz da; NERES, Geraldo Magella. Como estudar teoria política: textualismo, contextualismo linguístico e contextualismo social. In: SILVA, A; SILVA, V. S. V; DIAS, P. H. (Orgs.). Conectando mundos, repensando relações. Porto Alegre: UNIOESTE/Evangraf, 2016.

JASMIN, Marcelo Gantus. História dos conceitos e teoria política e social: referências preliminares. RBCS, v. 20, n. 57, fev. 2005.

NETTO, José Paulo. Nelson Werneck Sodré: o general da história e da cultura. São Paulo: Expressão Popular, 2011.

ROSA, Virginio Santa. O sentido do tenentismo. 3. ed. São Paulo: Alfa-Onega, 1976.

SEVERINO, Antônio Joaquim. Como ler um texto de filosofia. São Paulo: Paulus, 2014.

SILVA, Vania Sandeleia Vaz. O contextualismo social de Neal Wood e Ellen Meiksins Wood: uma introdução. In: V Simpósio Paranaense de Ciências Sociais, 5., 2016. Anais... Toledo: Edunioeste, 2016. SKINNER, Quentin. As fundações do pensamento político moderno. São Paulo: Companhia das Letras, 1996.

. Visões da política: sobre os métodos históricos. Algés: Difel, 2005.

SODRÉ, Nelson. Introdução à Revolução Brasileira. Rio de Janeiro: José Olympio Editora, 1958.

. Memórias de um escritor. Rio de Janeiro: Civilização Brasileira, 1970.

. Memórias de um soldado. Rio de janeiro: Civilização Brasileira, 1967.

STRAUSS, Leo. Perseguição e a arte de escrever. São Paulo: É Realizações, 2015.

TARCOV, Nathan; PANGLE. Thomas. Epílogo. Leo Strauss e a História da Filosofia Política. In: STRAUSS, L. História da Filosofia Política. Rio de Janeiro: Forense, 2013.

WOOD, Neal. The social history of political theory. Political Theory, v. 6, n. 3, 1978. 